\title{
Emergence and Development of Pottery in the Andean Early Formative Period: New Insights from an Improved Wairajirca Pottery Chronology at the Jancao Site in the Huánuco Region, Peru
}

\author{
Yuko Kanezaki, Takayuki Omori, and Eisei Tsurumi
}

\begin{abstract}
This article presents a high-resolution chronology of Wairajirca pottery in the Huánuco basin, which has been identified as a frontier region between the Andean highlands and the Amazonian rain forests: its pottery is known for having mixed features from both areas. However, the lack of fine-grained pottery and radiocarbon datasets has handicapped comparative studies' attempts to track in detail its early development process. Our new high-resolution chronology of Wairajirca pottery is based on stratigraphic excavation data, a detailed ceramic typology, and a Bayesian analysis of the radiocarbon date from the Jancao site. The five-staged ceramic sequence from the late eighteenth to late twelfth century cal BC displays specific features of this development, including radical changes in vessel type over several centuries and connections with other pottery traditions. The earliest phase shows close relation with highlands traditions, whereas the influence of tropical rain forest patterns intensified in later phases alongside the continuation of local pottery traditions. This indicates that frontier dynamics based on fluid interactions across different ecological zones and regional sociopolitical movements played a crucial role in this long-term social process.
\end{abstract}

Keywords: Wairajirca, Jancao, radiocarbon dating, Bayesian analysis, pottery chronology, emergence of pottery, Peruvian prehistory, Andean archaeology

Este artículo presenta una cronología de alta resolución de la cerámica Wairajirca en la cuenca de Huánuco, que ha sido considerada una región fronteriza entre la sierra andina y selva amazónica y su cerámica es conocida por tener características mixtas de ambas áreas. Sin embargo, la falta de una base afinada de datos sobre la cerámica y fechados radiocarbónicos asociados ha limitado los estudios comparativos para rastrear su proceso temprano de desarrollo. Nuestra nueva cronología de la cerámica Wairajirca se basa en datos de excavaciones estratigráficas, una detallada tipología de la cerámica y un análisis Bayesiano de los fechados radiocarbónicos del sitio Jancao. La secuencia cerámica de cinco etapas desde mediados del siglo dieciocho hasta fines del siglo duodécimo cal AC muestra cambios radicales en los tipos de vasija a lo largo del tiempo y conexiones con otras tradiciones alfareras. La primera fase tiene una estrecha relación con las tradiciones de la sierra, mientras que la influencia de la selva se intensificó en fases posteriores junto con la continuación de tradiciones alfareras locales. Esto indica que la dinámica de las fronteras basada en interacciones fluidas entre diferentes zonas ecológicas y movimientos sociopolíticos regionales desempeñaron un rol crucial en este proceso social a largo plazo.

Palabras clave: Wairajirca, Jancao, datación radiocarbónica, análisis Bayesiano, cronología de cerámica, aparición de la cerámica, prehistoria peruana, arqueología andina

$\mathrm{T}$ The appearance of pottery in the Central Andes is regarded as an important stage in the emergence of Andean civilization. This phenomenon, along with the preceding monumental architecture traditions based on a sedentary lifestyle, characterizes the Andean Early Formative period in the second millennium BC. The early evidence of pottery in the Central

Yuko Kanezaki (ykkanezaki@gmail.com, corresponding author) Graduate School of Humanities and Sociology, University of Tokyo, 7-3-1, Hongo, Bunkyo, Tokyo 113-0033, Japan

Takayuki Omori and Eisei Tsurumi — University Museum, University of Tokyo, 7-3-1, Hongo, Bunkyo, Tokyo 113-0033, Japan

Latin American Antiquity 32(2), 2021, pp. 239-254

Copyright (C) The Author(s), 2021. Published by Cambridge University Press on behalf of the Society for American Archaeology. This is an Open Access article, distributed under the terms of the Creative Commons Attribution licence (http://creativecommons.org/licenses/by/4.0/), which permits unrestricted re-use, distribution, and reproduction in any medium, provided the original work is properly cited.

doi:10.1017/laq.2020.89 
Andes dates back to late Preceramic period offerings (e.g., Grieder 1988) that were possibly imported from other areas with much earlier pottery development. Scholars have used various models to explain this phenomenon, such as diffusionist explanations (Ford 1969; Kaulicke 1981; Lathrap 1971; Meggers et al. 1965) and the indigenous invention model (Burger 1988; Hoopes 1994). Whichever models are chosen, it is evident that a broad transaction network existed around the Central Andes, playing a significant role in the social process of adopting pottery technology in this area, and that frontier regions would have played an important role in these networks.

The Huánuco region, located in the eastern slopes of the Andes and comprising a narrow valley formed by the upper Huallaga River, is one of the frontier regions situated between the Andean highlands and the Amazonian rain forests. Scholars have paid great attention to this region's pottery because of its unique variety of vessels and characteristic decoration (e.g., Burger 1992; DeBoer 2003; Kano 1979; Lathrap 1970, 1971; Meggers et al. 1965). Pottery in the Andean western slopes, including the highlands and coastal areas, in the Early Formative period had rather thin vessel walls with plain or simple decorations and were made with relatively coarse paste. The ceramic assemblage in the western slopes mainly consisted of neckless jars and bowls, of which there were local varieties, such as the nicked applique strips observed in the north and north-central coasts and highlands (Burger 1985; Kaulicke 1981; Nesbitt et al. 2010; Terada and Onuki 1985; Tsurumi 2010). In contrast, pottery in the Amazonian rain forests included a wide variety of vessel forms with elaborate decorations, such as wide-mouthed jars, carinated bowls, and bottles with bridged handles (Lathrap 1970). The Huánuco region pottery assemblage combined characteristics from pottery in the highlands and the tropical rain forests; there were various vessel forms in this region, including neckless jars, wide-mouthed jars, boat-shaped or triangleshaped bowls, double-spout bottles with bridged handles, and decorations such as complicated geometric motifs with postfired pigment (Onuki 1972). Archaeological researchers have variously suggested that this ceramic assemblage may be related to the neighboring eastern lowlands (Lathrap 1962, 1970, 1971), to a far northern area in the eastern slopes (Shady 1987), or to a southern highland area (Chávez 1977).

Research on the Early Formative period is fraught with chronological issues related to ceramic sequences and absolute time scales. The detailed typological pottery sequences or serial changes in ceramic styles have not been described in many regions, mainly due to a lack of fine-grained ceramic data based on stratigraphic excavation. In addition, researchers have developed various ceramic typologies based on the application of different criteria to individual sites. This has made it difficult to compare pottery styles across broad areas. Many of the absolute dates associated with ceramic sequences were determined by early radiocarbon measurements. These dates are relatively uncertain due to measurement technique issues or data corrections (for a more comprehensive review and critique of the dates of early pottery in Peru, see Hoopes 1994). Furthermore, insufficient statistical evaluations of radiocarbon data corresponding to ceramic sequences have limited archaeological interpretation. Thus, researchers have not yet reached a consensus regarding each pottery tradition's age and duration. This lack of consensus has restricted the degree to which interregional comparative studies can be conducted and has resulted in difficulties for researchers in exploring the detailed development track of early Andean pottery.

In this study, we present a high-resolution chronology of the Jancao site in the Huánuco region based on fine-grained pottery datasets anchored by a Bayesian radiocarbon analysis. A detailed typological analysis of ceramic sherds, as well as a Bayesian analysis of the radiocarbon dates, reveals the Wairajirca ceramic sequence in a fine time scale. These analyses will enable comparative studies across the broad areas within and outside of the Central Andes. The proposed chronology and a brief comparative review of early pottery in the neighboring regions allow us to determine some possible features of Wairajirca pottery's development over several centuries in relation to frontier dynamics (Parker 2006). 


\section{The Jancao Site}

The Jancao site $\left(76^{\circ} 13^{\prime} 22^{\prime \prime} \mathrm{E}, 09^{\circ} 63^{\prime} 55^{\prime \prime} \mathrm{S}\right.$, $1,925 \mathrm{~m}$ asl), which is the present-day Amarilis district in Peru's Huánuco province, is located on the alluvial land on the southern bank of the Huallaga River. The surrounding environment belongs to the fertile yunga zone (Pulgar Vidal 1987), and the neighborhood includes several key archaeological sites of the Formative period, such as Kotosh, Wairajirca, and Shillacoto (Figure 1; Inokuchi et al. 2002; Matsumoto 2020; Onuki 1993).

The earliest archaeological investigations in the Huánuco region occurred in the 1960s and focused primarily on the study of the Formative period (Izumi and Sono 1963; Izumi and Terada 1972; Izumi et al. 1972; Kano 1979; see also Matsumoto 2020). These studies identified the Wairajirca phase, the local phase of the Early Formative period in this region. Onuki (1972) analyzed the ceramic assemblage at the Kotosh site and classified all unearthed sherds, mainly by their decoration technique (such as shallow incised, zoned hachure, red plain, etc.). These studies, however, did not clearly detail a chronological sequence for Wairajirca pottery.

The Jancao site, which was found by a 2001 archaeological survey of settlement patterns (Inokuchi et al. 2002; Matsumoto 2020), is one of the largest artificial mounds dated to the Formative period in the Huánuco region. The site was badly damaged by modern activities, including road construction. As such, our 2017 excavation was conducted in limited areas (Supplemental Figure 1). We found accumulation of cultural deposit from the Initial Formative period to the Early Intermediate period by observing the site's profile and the surface collection of ceramic sherds. However, there was very little left of the accumulation's upper parts to excavate. Thus, the great majority of the cultural deposit of the excavated area appeared to belong to the Early Formative period, the Wairajirca phase.

This mound site is basically composed of artificial accumulation. In other words, layers were formed by human activities mainly associated with centuries of building construction during serial (continuous or continual) occupation. In the Wairajirca phase deposit, each layer accumulated horizontally and was several dozen centimeters thick. This accumulation's formation would have been a result of the following process: (1) the collapsing or destruction of buildings made in a period and (2) a covering with earth and rocks to make foundations for new construction. This process would be repeated various times during the Wairajirca phase, forming consequent serial accumulations for several centuries, although the limited excavation did not find direct evidence of construction. Under the Wairajirca phase layers, an earth layer emerged that did not include any ceramic sherds, making it highly possible that it belonged to the preceramic period.

To construct a highly accurate Wairajirca phase chronology, we selected two excavation units, E1N4 and E1S2-3, in which each layer remained clear without massive disturbances by later deposits (Figure 2; also see Supplemental Figure 2). We also used two approaches to clarify the ceramic sequence in a fine time scale: a typological pottery analysis and a Bayesian radiocarbon dating analysis.

\section{Typological Pottery Analysis}

We relied on a qualitative analysis of pottery sherds, based on morphological typology, to develop a ceramic sequence of the Jancao site. The new type classification is intended to create a finer relative chronology and to facilitate comparative analyses of pottery across various sites. From the collection of ceramic sherds unearthed in E1N4 and E1S2-3, we selected for analysis a total of 371 rim sherds and a few other fragments from which we could reconstruct vessel forms. Next, the following seven kinds of vessel forms were reconstructed: neckless jars, wide-mouthed jars, carinated bowls (with convex base), closed bowls (with rounded base), open semi-spherical bowls, boat-shaped bowls, and bottles with bridged handles. We then defined the types according to certain vessel attributes, focusing on specific profile and decoration features that were notably more "time-sensitive" than other ceramic traits. For example, certain features can be used as time marks: the rim shape of neckless jars; a thickened, beveled, tapered, and decorative element; punctate lines; arc shapes; and so 

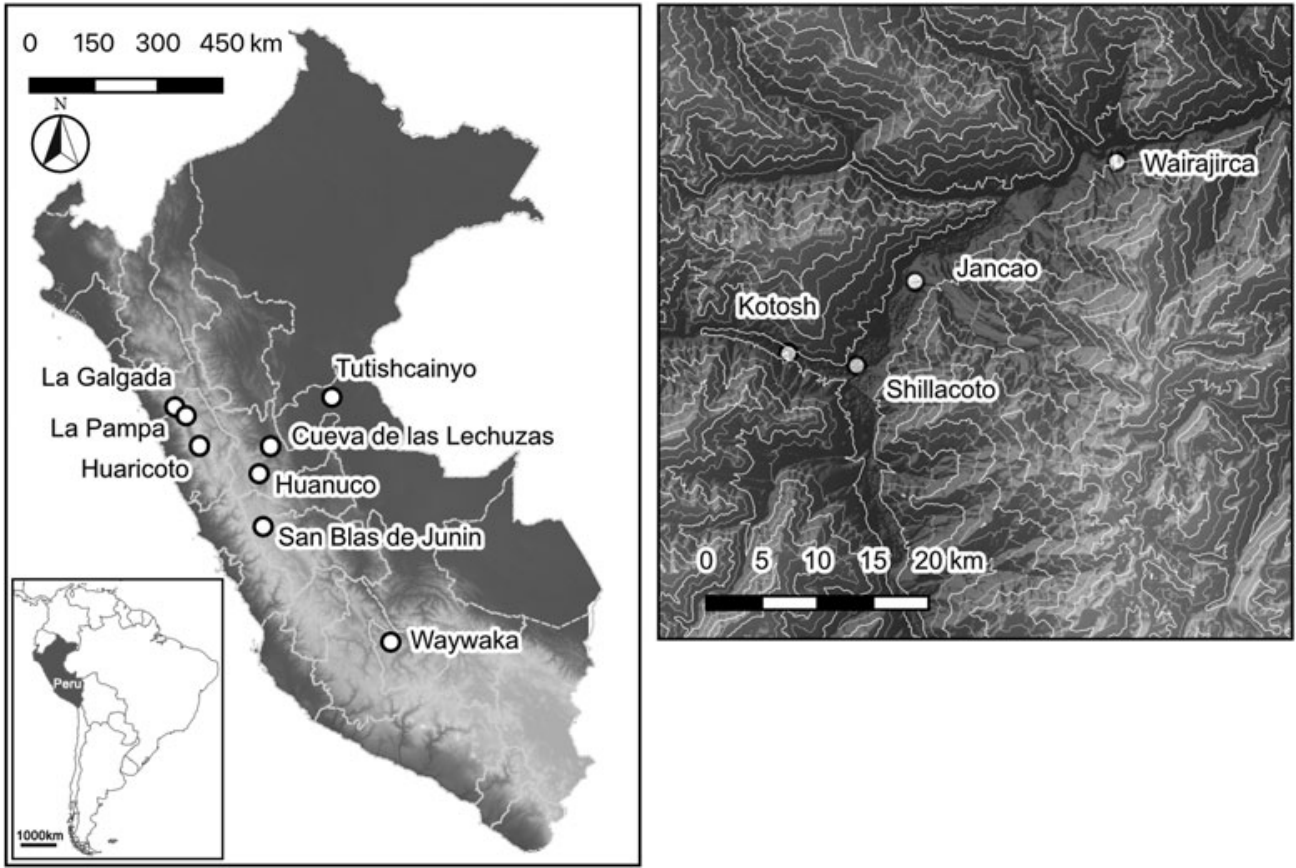

Figure 1. Map of the Central Andes (left) and the Huánuco region (right) with site locations.
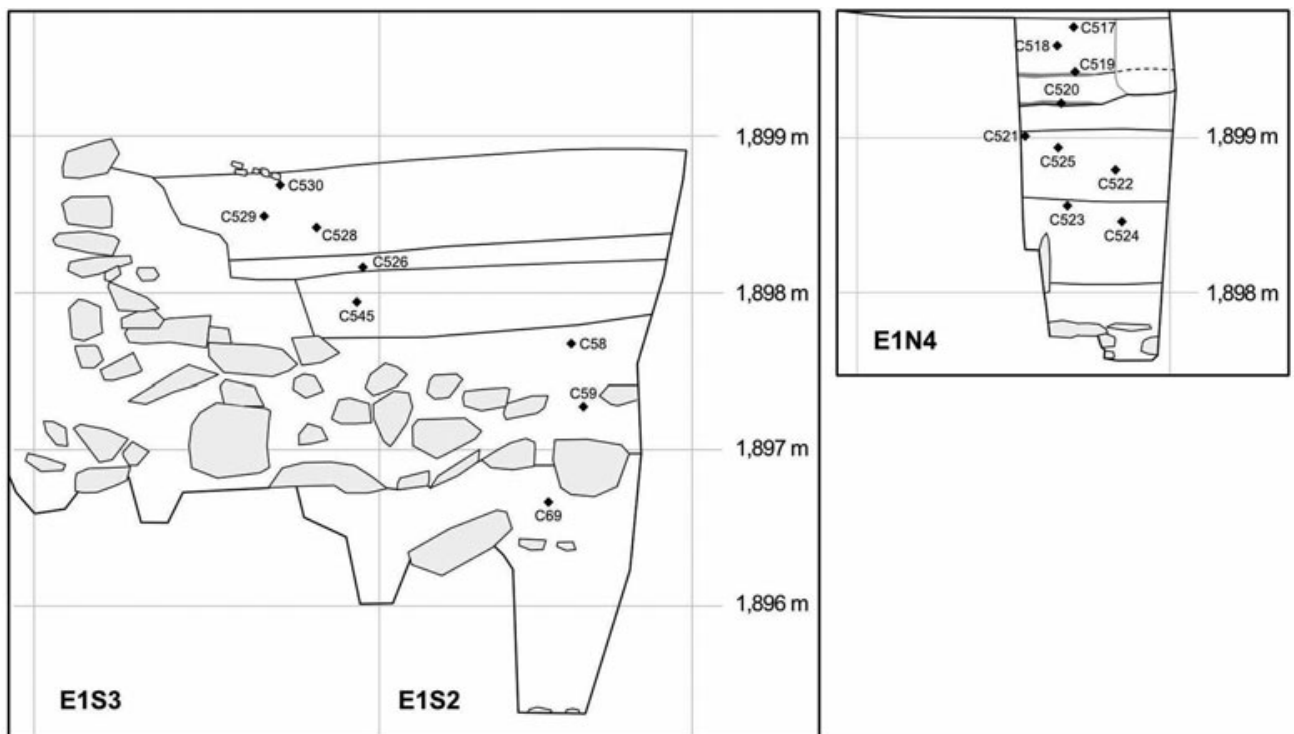

Figure 2. Stratigraphy of selected excavation units, E1N4 and E1S2-3, with plots of the carbon sample locations.

on. We also defined the ceramic phases by comparing types according to their stratigraphic units. Consequently, we described the site's ceramic sequence as the serial change of the type set following the stratigraphic order.
Regarding the depositional context constraints, it is necessary to consider the possibility that the sample was mixed with sherds from older layers. Thus, we only chose types that had appeared in the assemblage for the first time to 
represent each type for each layer. In drawing, we applied the wet-rubbed copy method (for details, see Matsumoto 2014).

\section{Radiocarbon Dating and Bayesian Analysis}

We used radiocarbon dating and a Bayesian analysis to develop an absolute time scale. A continuous and systematic radiocarbon analysis of Early Formative contexts allows researchers to assess a site's occupation sequence and reveals an accurate temporal distribution based on stratigraphic units. The samples were collected at the cross section of E1N4 and E1S2-3. There were various burnt accumulation lenses or charcoal inclusion layers within the Early Formative contexts. We selected in situ charcoal fragments from a bottom layer to the top fill of each horizontal accumulation unit and applied a Bayesian analysis by considering the stratigraphic contexts and number of samples/data points (Figure 2). The date of the unit bottom is essential for directly estimating the timing of occupations, and the fill's temporal information enables researchers to understand the duration and transition of archaeological finds. The sequential sampling was independently set at both excavation units to avoid any confusion in interpreting the stratigraphic contexts. We cross-referenced the samples with the parallel sequence, which enabled us to evaluate the radiocarbon results and helped us construct a robust and accurate age model for the pottery assemblages.

We conducted radiocarbon analyses of the collected samples at the Laboratory of Radiocarbon Dating, University Museum, University of Tokyo. Via microscopic observations, we included charred fragments that have wellpreserved plant tissue (excluding unknown charred substances) in the sample. Almost all the samples appeared like young trees or small branches and had no fine width growth/tree rings, which are developed over several hundreds of years (Supplemental Figure 3). We applied an acid-base-acid pretreatment, commonly used to remove burial contaminants, to the samples and then converted to the measurement target substance for accelerator mass spectrometry (AMS). We calculated the conventional radiocarbon age with ${ }^{14} \mathrm{C}$ measurements and obtained $\delta^{13} \mathrm{C}$ from the compact-AMS system (0.5MV 1.5SDH-1 Pelletron, National Electrostatics Corp.). Age calibrations, which were followed by Bayesian analyses, were performed with OxCal v4.3 (Bronk Ramsey 2009a). These figures were calculated using the SHCal13 atmospheric curve (Hogg et al. 2013). However, it might be necessary to consider the effect of the Northern Hemisphere air in relation to the dynamics of the Intertropical Convergence Zone or South American Summer Monsoon, given the site location in temperate latitudes. To compare the calendar dates, we also referred to the mixed atmospheric curve described by Marsh and others (2018).

We employed the Bayesian analysis to increase the accuracy of the individually calibrated dates, estimate the duration of the pottery assemblages, and assess the depositional process of the Wairajirca stratum. Bayesian constraints defined by stratigraphic contexts can refine interpretations of calibrated dates to a higher likelihood (Bronk Ramsey 1995; Christen 1994). We also used a Bayesian analysis to simulate the optimal event date, such as a transition between cultural activities. The likelihood date, which is expressed as a probability, can be extracted from convergence and variability in the radiocarbon results (Bronk Ramsey 1998). The following discussion is based on the dates estimated from the boundary between pottery assemblages.

Furthermore, identifying any inconsistencies between the radiocarbon data and stratigraphic information enables an assessment of the occupation sequence. If the radiocarbon data deviate from a certain set of archaeological contexts, it is possible that extant archaeological assumptions do not match the actual analysis samples' provenances. In other words, the degree of model agreement suggests the disturbance of stratigraphic superposition, such as a reworking of the deposits. The agreement degree is quantified by an agreement index and represented by comparisons with expectations of the calibrated and modeled dates (Bronk Ramsey 1995). The Bayesian analysis for outlier estimates is used to derive the outlier probability with a priori outlier probabilities, set at 5\% (Bronk Ramsey 
2009b). Using the two indexes, we reviewed the archaeological stratification from the standpoint of the depositional process of charcoal.

Finally, the possibility of systematic age offsets due to the old wood effect was examined by a charcoal model - one of the Bayesian outliers' analyses (Bronk Ramsey 2009b). The charcoal model gives the charred dates an arbitrary old wood effect and estimates the likelihood dates eliminated from the age offset. We assumed that the old wood effect between 0 and 100 years exists in the measured samples and compared our results with that of other age models.

\section{Ceramic Sequence}

We separated the Wairajirca ceramic sequence at the Jancao site into five phases (I-V). As discussed in more detail later, this ceramic classification strongly corresponded with the absolute dating results. Figures 3 and 4 display a set of ceramic types from each phase (see Supplemental Figures 4-9 for more detailed data).

The features of pottery from the earliest phase of the Jancao site are considerably different from those of the later phases. Neckless jars are the only vessel forms that were reconstructed in this first phase, and they do not have any decorations. Their surface treatment is rather coarse, and they seem to have been fired under poorly controlled conditions. Those neckless jars are divided into two types based on rim form: one has thickened rims (like a comma shape), and the other has rims that are rather thin and flat or slightly beveled.

Pottery from Phase II was more elaborate than that of Phase I. Phase II pottery featured plenty of decorated sherds. The assemblage consisted of neckless jars, closed bowls and convex base bowls, and bottles with bridged handles. Unlike in Phase I, there were no neckless jar sherds with thin rims. The different vessel forms shared essentially the same decoration style. This style can be divided into three types: (1) a row of small punctuation below the lip, (2) a row of short incisions with a line around the rim, and (3) a combination of punctuation and incisions (which sometimes included scale-like motifs/ appliqués and was often more elaborate). In addition, some closed bowls had an arc-shaped decorative motif that likely held some connection with the next phase's neckless jars. One fragment had dense, short incisions with a rope-like appearance on the lip. As for the bottles with bridged handles, we only uncovered spouts and handles with highly polished black exteriors.

There was a major change between Phase II and Phase III pottery at the Jancao site. This change is most clearly indicated by the introduction of new vessel forms and decoration techniques: the wide-mouthed jar and red slip, respectively. The neckless jar decoration featured an arc-shaped motif by shallow incision. It appears that this decorative style can be divided into two subcategories. One type is relatively simple and is associated with short incisions or punctuations; the other type features punctuations in a square and has a more elaborate impression. As in Phase II, in Phase III the thickened rim predominated among neckless jars. The wide-mouthed jars include a type that had an extremely short neck and resembled the neckless jar. This type was elaborately decorated with specific geometric motifs, including the small circle and dots. In this phase, the red slip technique was applied to some wide-mouthed jars.

The pottery assemblage of Phase IV featured two different decoration styles. One decoration style is connected to previous phases and is mainly associated with neckless jars. The other style, however, seems to have suddenly appeared in this phase and is closely related to carinated bowls. The primary decoration of neckless jars still had arc-like motifs but was rather simple, featuring shallow and thin incisions; for certain neckless jars, a burnished technique was used. In contrast to the previous phases, the red slip was often applied to the neckless jars and the tapered rim predominated. Some Phase IV neckless jars had ridged rims, with shapes and decorations that seemed to have followed the previous phase's wide-mouthed jars. Bowls featured geometric motifs with hatching-like incisions, and a postfired pigment was applied to the carinated bowls (whose surface was blackish and well polished). Some bowls contained circle-and-dot motifs and pigmented matte depressed zones. This phase's sample also included one fragment from a possible bottle body with hatching and pigmented decoration on a black polished 


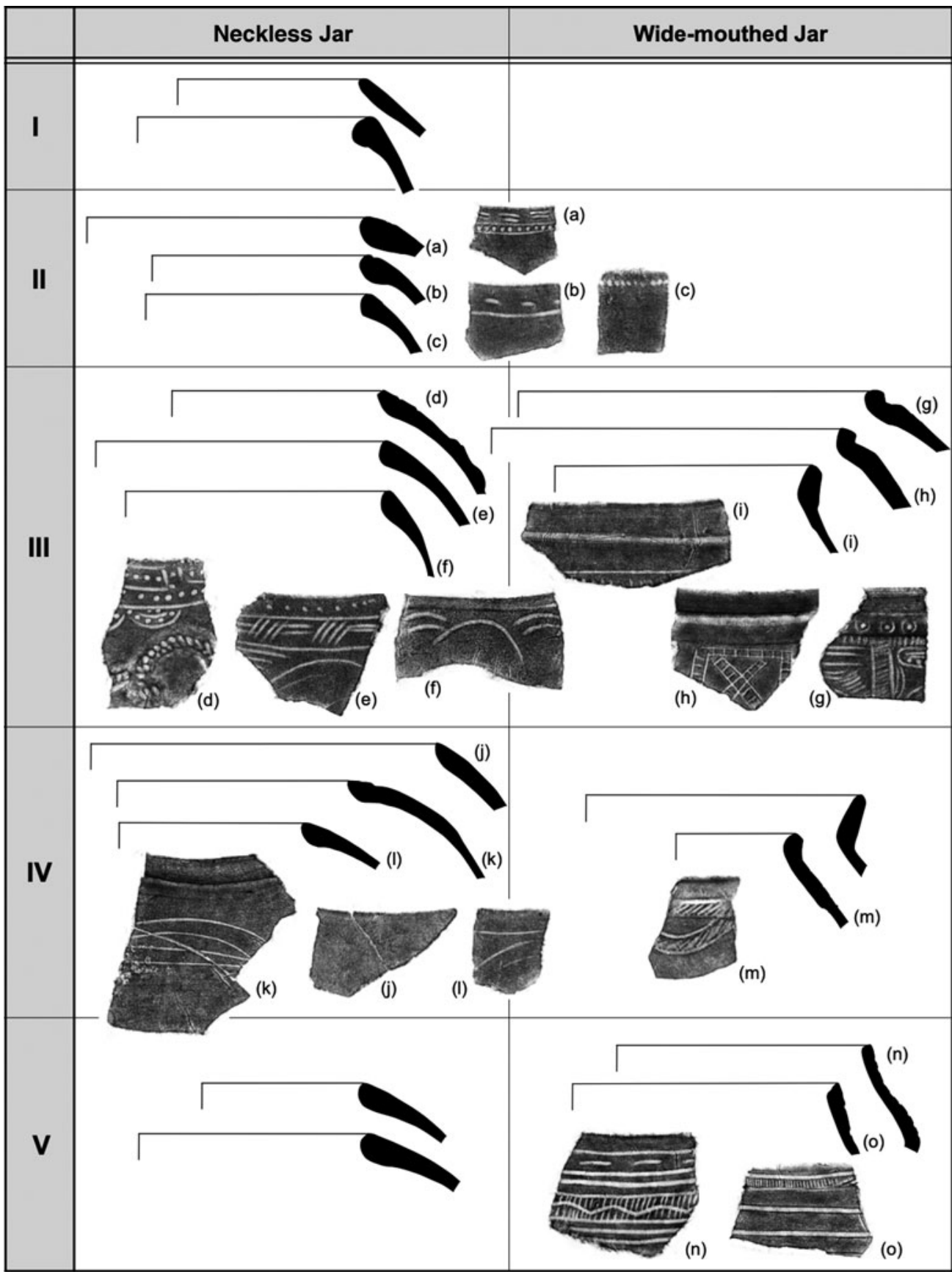

Figure 3. Ceramic sequence of neckless jars and wide-mouthed jars (including small-sized ones that possibly belong to the bowl category) at the Jancao site. Each fragment in a rank represents a type that is specific to one phase.

surface. This phase's stylistic dichotomy basically matches Toshihara's (2002) description, although she described it as a feature of the entire assemblage of Wairajirca pottery.
The final phase's assemblage consists of a wide variety of vessel forms: neckless jars, carinated bowls, wide-mouthed jars, open semispherical bowls, and boat-shaped bowls. In this 


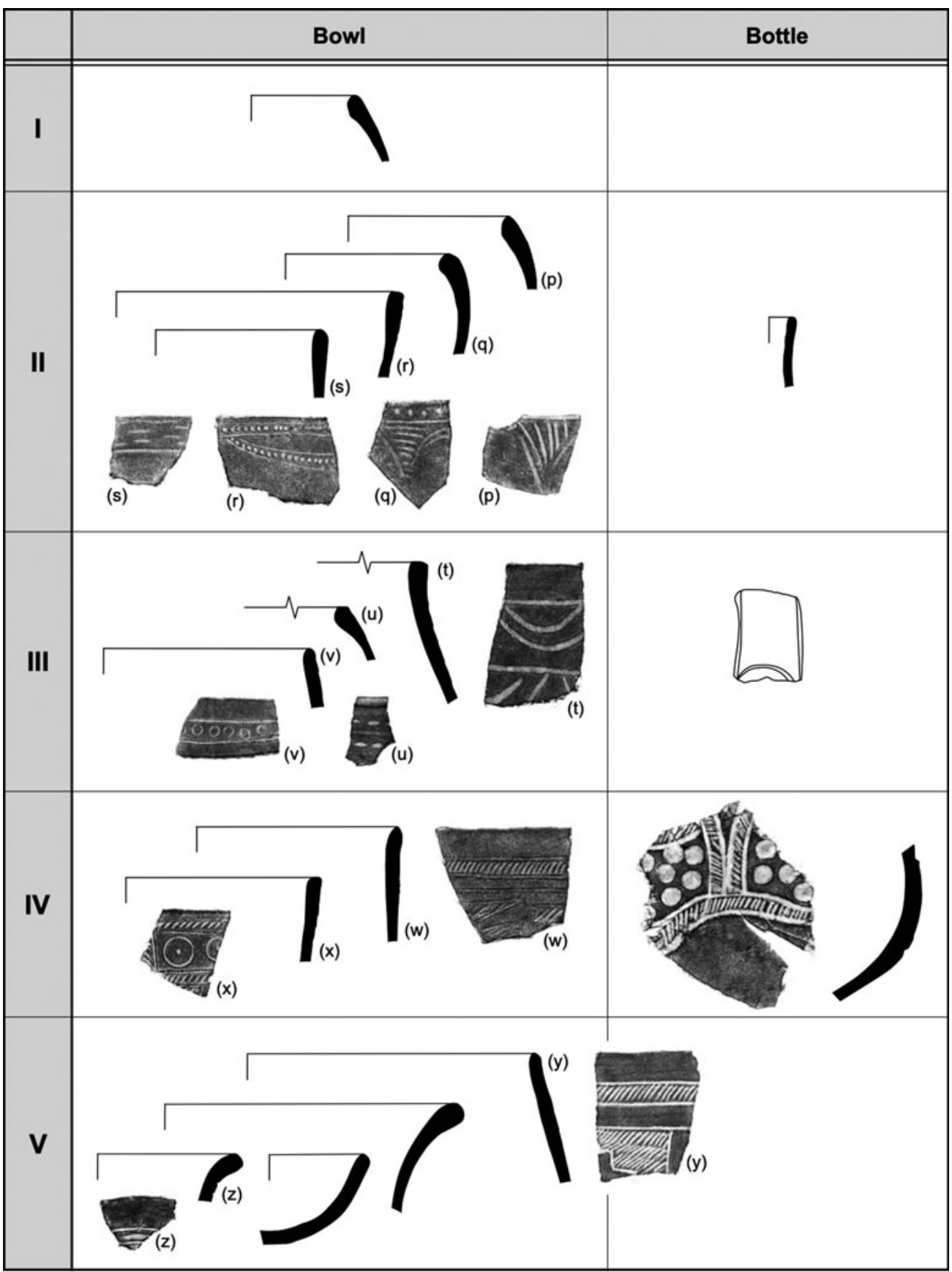

Figure 4. Ceramic sequence of bowls and bottles at the Jancao site.

phase, most neckless jars are without decorations, both slipped and nonslipped, with a thickened rim. The carinated bowls still have hatching and pigmented decorations, although the incisions on these are denser and longer. Hatchings were also applied to the middle-sized bowls in forms that resemble the neckless and widemouthed jars. This phase contains two new vessel types: open semi-spherical bowls and boatshaped bowls. The former is plain, and the latter 
can be divided into two types: one is plain and often red slipped, and the other is polished black and associated with broad line incisions, postfired pigment, and zoned hatching.

\section{Absolute Chronology}

Table 1 presents the radiocarbon results for the 17 charcoal samples and the Bayesian estimates. Figure 5 summarizes the modeled dates on SHCal13 with boundary distributions. The estimates of the mixed atmospheric curve and the charcoal model are shown in Supplemental Table 1. For the Bayesian models, we used the stratigraphic order defined by the actual sampling positions as a vertical relationship and assumed the five groups identified from the pottery assemblages as a horizontal relationship to combine the parallel sequences of the grid E1N4 and E1S2-3 (Supplemental Figure 10).

The charcoal radiocarbon measurements of the Wairajirca phase fell within about $3500 \mathrm{BP}-$ 2900 BP (from the eighteenth century cal BC to the twelfth century cal BC). They seem to converge into five distributions around 3400 BP, 3300 BP, 3100 BP, 3000 BP, and 2900 BP, which synchronize with the stratigraphic subdivisions. This distribution pattern would strongly underpin the pottery classification results. The chi-square test results for the radiocarbon measurements grouped in Wairajirca V, Wairajirca IV, and Wairajirca II indicate that there are no significant differences for each age (Wairajirca $\mathrm{V} T^{\prime}=3.62, \chi^{2}=9.49[p=0.05], d f=4$; Wairajirca IV $T^{\prime}=0.05, \chi^{2}=3.84[p=0.05], d f=1$; Wairajirca II $T^{\prime}=6.05, \chi^{2}=7.82 \quad[p=0.05]$, $d f=3$ ). These outcomes may imply that these three phases reflect snapshots formed within a limited period. However, age differences around 100 years appeared in Wairajirca III (TKA-19533, 19562, 19554, and 19582), which indicates that there were at least two occupational events in the deposition.

The Bayesian model results suggested the following calendar dates: late eighteenth century to early seventeenth century cal BC (Wairajirca I), early sixteenth century to early fifteenth century cal BC (Wairajirca II), late fifteenth century to late fourteenth century cal BC (Wairajirca III), early thirteenth century to late thirteenth century cal BC (Wairajirca IV), and early twelfth century to late twelfth century cal BC (Wairajirca V). These estimates exhibited no large differences when using either the mixed atmospheric curve or assuming the old wood effect. Compared with the modeled dates on SHCal13, the mixed curve model and the charcoal model appeared 25 years older and 15 years younger, respectively, on average (Supplemental Table 1). We should keep in mind that age may vary for a maximum of 40 years according to the respective conditions, but this had little to no impact on our phase classification.

Each phase's start and end dates are represented by the median of the calculated boundaries as the most likely estimates. The phase durations, ranging from 80 to 170 years, indicate that transitions between phases of pottery proceeded quickly. The continuance in the age model implies that the Wairajirca depositions at the Jancao site were periodic and continuous.

The agreement index and outlier probability results indicate that the defined stratigraphic subdivision is consistent with the radiocarbon results. Because each data's agreement indexes were higher than $60 \%$ for a similar discrimination to the $\chi^{2}$ test at $5 \%$ and the outlier probabilities remained small (Table 1), it is possible that there were no disturbances over the phases in the deposits. Thus, it can be assumed that the behavior of the archaeological inclusions remained the same along the deposition process and that the provenances of the analyzed pottery shards directly corresponded to the phrase's terminus post quem.

\section{Indication of Relationships with Other Regions' Pottery Traditions}

Certain vessel types, decorative styles, and techniques appearing in each phase are closely related to other regions' pottery traditions. The neckless jars with thin rims that were unique to the first phase closely resemble neckless jars found in the early stages of various north-central and south-central highland sites, including the Yesopampa phase of the La Pampa site (Terada 1979:PL.105-107), the Toril phase of the Huaricoto site (Burger 1985:Figures 3-6), the second phase of the La Galgada site (Grieder 1988: 
Table 1. Radiocarbon Determinations of Charcoals from the Jancao Site.

\begin{tabular}{|c|c|c|c|c|c|c|c|c|c|c|c|c|}
\hline \multirow[b]{2}{*}{ Phase } & \multirow[b]{2}{*}{ Grid } & \multirow[b]{2}{*}{ Sample name } & \multirow[b]{2}{*}{ Lab code } & \multirow[b]{2}{*}{${ }^{14} \mathrm{C}$ age $(\mathrm{BP})$} & \multirow[b]{2}{*}{$\delta^{13} \mathrm{C}(\%)$} & \multicolumn{2}{|c|}{ Calibrated date (cal BC) } & \multicolumn{3}{|c|}{ Modeled date (cal BC) } & \multirow[b]{2}{*}{ AI } & \multirow[b]{2}{*}{ Outlier } \\
\hline & & & & & & $68.2 \%$ prob. & $95.4 \%$ prob. & $68.2 \%$ prob. & $95.4 \%$ prob. & Median & & \\
\hline End Wairajirca $V$ & & & & & & & & $1185-1110$ & $1200-1060$ & 1140 & & \\
\hline \multirow[t]{6}{*}{ Wairajirca V } & E1N4 & 17JCA-C517 & TKA-19549 & $3019 \pm 21$ & $-24.0 \pm 0.5$ & $1260-1125$ & $1370-1055$ & $1190-1115$ & $1205-1070$ & 1145 & 81.7 & 5 \\
\hline & & 17JCA-C518 & TKA-19550 & $2955 \pm 22$ & $-20.4 \pm 0.4$ & $1195-1040$ & $1210-1010$ & $1190-1115$ & $1210-1075$ & 1150 & 92.9 & 4 \\
\hline & & 17JCA-C519 & TKA-19551 & $2987 \pm 24$ & $-21.0 \pm 0.5$ & $1220-1110$ & $1260-1040$ & $1195-1115$ & $1210-1080$ & 1155 & 120.8 & 3 \\
\hline & E1S3 & 17JCA-C530 & TKA-19567 & $2974 \pm 24$ & $-23.6 \pm 0.3$ & $1210-1055$ & $1225-1015$ & $1190-1100$ & $1195-1055$ & 1145 & 115.7 & 3 \\
\hline & & 17JCA-C529 & TKA-19566 & $2983 \pm 24$ & $-28.1 \pm 0.3$ & $1215-1090$ & $1260-1030$ & $1195-1100$ & $1200-1060$ & 1145 & 115.1 & 3 \\
\hline & & 17JCA-C528 & TKA-19565 & $2903 \pm 24$ & $-27.4 \pm 0.3$ & $1110-975$ & $1125-920$ & $1195-1105$ & $1205-1065$ & 1150 & 28.2 & 14 \\
\hline Start Wairajirca $V$ & & & & & & & & $1210-1120$ & $1235-1090$ & 1175 & & \\
\hline End Wairajirca IV & & & & & & & & $1255-1190$ & $1285-1150$ & 1220 & & \\
\hline \multirow[t]{2}{*}{ Wairajirca IV } & E1N4 & 17JCA-C520 & TKA-19552 & $3053 \pm 20$ & $-21.1 \pm 0.4$ & $1370-1205$ & $1390-1125$ & $1270-1220$ & $1300-1195$ & 1245 & 129.9 & 4 \\
\hline & E1S3 & 17JCA-C526 & TKA-19563 & $3048 \pm 24$ & $-24.9 \pm 0.3$ & $1370-1130$ & $1385-1125$ & $1270-1215$ & $1300-1195$ & 1245 & 132.7 & 4 \\
\hline Start Wairajirca IV & & & & & & & & $1305-1235$ & $1350-1210$ & 1270 & & \\
\hline End Wairajirca III & & & & & & & & $1375-1290$ & $1400-1255$ & 1330 & & \\
\hline \multirow[t]{4}{*}{ Wairajirca III } & E1N4 & 17JCA-C521 & TKA-19533 & $3111 \pm 24$ & $-19.8 \pm 0.4$ & $1395-1280$ & $1420-1230$ & $1395-1335$ & $1410-1290$ & 1360 & 112.8 & 3 \\
\hline & & 17JCA-C525 & TKA-19562 & $3077 \pm 24$ & $-24.5 \pm 0.4$ & $1380-1225$ & $1405-1135$ & $1400-1345$ & $1410-1300$ & 1370 & 79.4 & 5 \\
\hline & & 17JCA-C522 & TKA-19554 & $3132 \pm 22$ & $-19.6 \pm 0.4$ & $1410-1300$ & $1430-1270$ & $1410-1350$ & $1420-1300$ & 1380 & 107.4 & 4 \\
\hline & E1S3 & 17JCA-C545 & TKA-19582 & $3216 \pm 26$ & $-23.5 \pm 0.4$ & $1500-1415$ & $1515-1320$ & $1445-1320$ & $1470-1300$ & 1410 & 60.0 & 8 \\
\hline Start Wairajirca III & & & & & & & & $1490-1390$ & $1510-1320$ & 1435 & & \\
\hline End Wairajïra II & & & & & & & & $1525-1445$ & $1595-1395$ & 1485 & & \\
\hline \multirow[t]{4}{*}{ Wairajirca II } & E1N4 & 17JCA-C523 & TKA-19555 & $3306 \pm 21$ & $-18.6 \pm 0.4$ & $1610-1500$ & $1620-1450$ & $1530-1475$ & $1605-1445$ & 1505 & 87.6 & 4 \\
\hline & & 17JCA-C524 & TKA-19556 & $3338 \pm 21$ & $-20.7 \pm 0.5$ & $1615-1530$ & $1645-1500$ & $1540-1485$ & $1610-1460$ & 1515 & 110.9 & 4 \\
\hline & $\mathrm{E} 1 \mathrm{~S} 2$ & 17JCA-C58 & TKA-19526 & $3256 \pm 26$ & $-23.1 \pm 0.7$ & $1510-1440$ & $1610-1410$ & $1545-1500$ & $1605-1495$ & 1525 & 116.9 & 5 \\
\hline & & 17JCA-C59 & TKA-19527 & $3275 \pm 25$ & $-15.4 \pm 0.7$ & $1530-1445$ & $1615-1430$ & $1560-1505$ & $1610-1500$ & 1535 & 94.5 & 4 \\
\hline Start Wairajirca II & & & & & & & & $1610-1515$ & $1670-1500$ & 1570 & & \\
\hline End Wairajirca I & & & & & & & & $1725-1610$ & $1775-1535$ & 1665 & & \\
\hline Wairajirca I & E1S2 & 17JCA-C69 & TKA-19530 & $3472 \pm 25$ & $-18.0 \pm 0.6$ & $1865-1680$ & $1880-1640$ & $1750-1660$ & $1865-1620$ & 1705 & 102.1 & 6 \\
\hline Start Wairajirca I & & & & & & & & $1790-1665$ & $1915-1625$ & 1735 & & \\
\hline
\end{tabular}




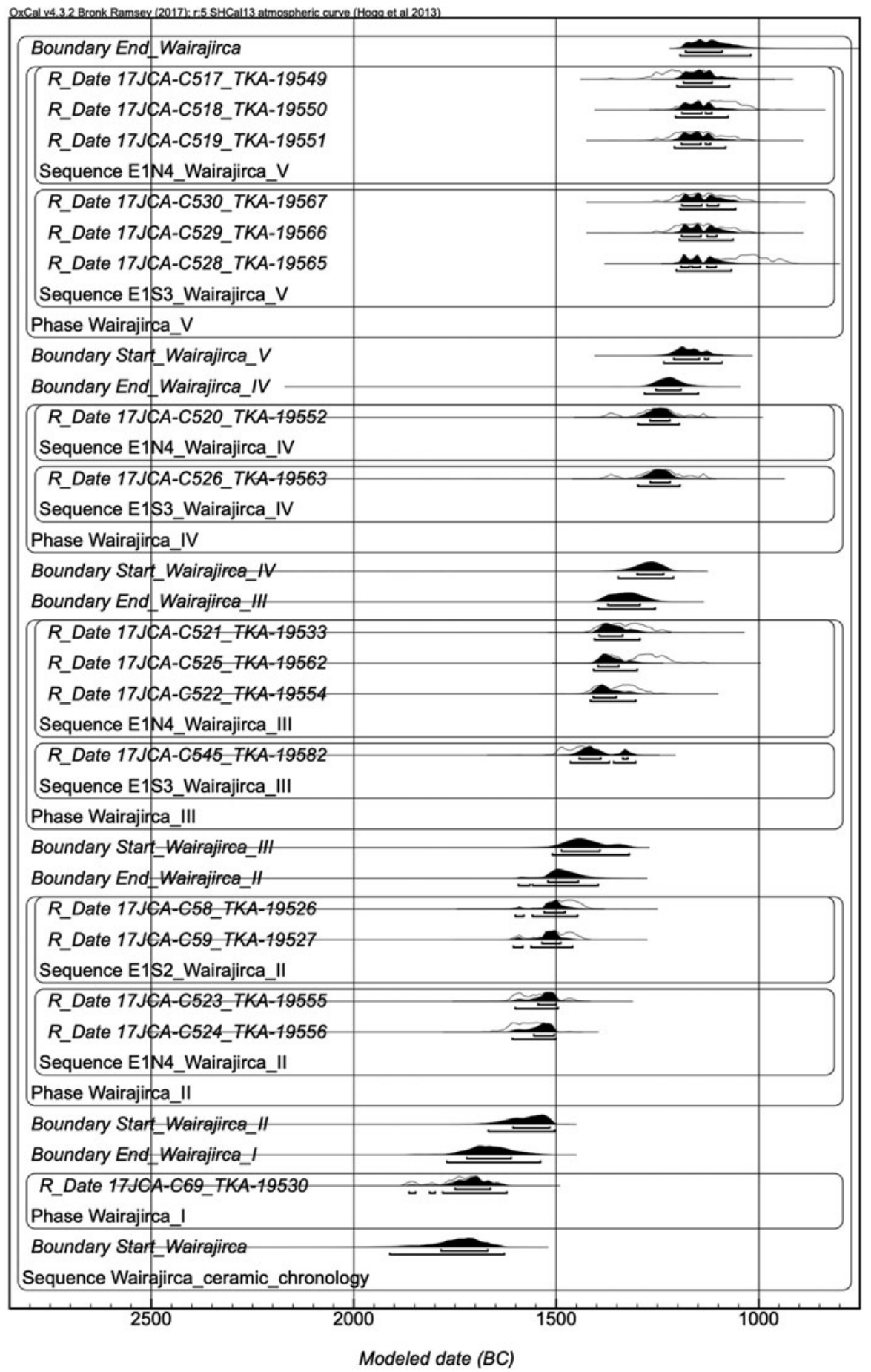

Figure 5. The modeled dates for the Jancao sequence produced using OxCal 4.3 (Bronk Ramsey 2009a). The radiocarbon ages are calibrated using the Southern Hemisphere atmospheric curve SHCal13 (Hogg et al. 2013). The model is built based on the stratigraphic order defined by the actual sampling positions (see Supplemental Figure 10 and Supplemental Note 1 for the diagram of stratigraphic relations and OxCal CQL2 codes, respectively). Lighter shaded distributions are calibrated radiocarbon likelihoods, whereas darker outline distributions are posterior probabilities after the Bayesian modeling. The $68 \%$ and $95 \%$ probability ranges are given by the horizontal brackets beneath the probability densities. 
Figures $156 \mathrm{q}-\mathrm{u}$ ), the Initial period of the San Blas de Junín site (Morales 1998:Figure 17), and the Muyu Moqo A phase of the Waywaka site (Grossman 1983:Figures 7-13). This similarity, however, did not continue in the following phases, in which decorated neckless jars with thickened rims flourished. The San Blas de Junín site, located in the Junín plateau only $100 \mathrm{~km}$ south of the Huánuco region, is one possible post-phase I connection between the Huánuco region and the highlands. At this site, the plain neckless jars changed between the first and second phases in a similar way to the changes observed in the Jancao site (Morales 1977, 1998). However, the decorative style that was mainly associated with the neckless jars from phases II, III, and IV is not associated with any other region. Thus, it appears that the emergence and successive change of this style are best explained by local development.

In contrast, the decorative style with hatching and postfired pigment that emerged in phase IV is related to a neighboring tropical forest's pottery traditions (Izumi and Terada 1972; Izumi et al. 1972; Kano 1979). Lathrap (1971) indicated that Tutishcainyo pottery traditions, located in the central Ucayali basin around the modern town of Pucallpa and dated to the Early Formative period, had a specific influence on Wairajirca pottery. Similar decoration techniques featuring geometric and animal face motifs have been observed at the Cueva de las Lechuzas site, located approximately $100 \mathrm{~km}$ east of the Huánuco region (Lathrap and Roys 1963:Figures 1-4). When exploring the resemblance of the Tutishcainyo and Cueva de las Lechuzas examples to Wairajirca pottery, however, it is important to consider that vessels found with such decorations at those sites have marked differences from the Wairajirca assemblage. For instance, Tutishcainyo pottery includes a relatively shallow, carinated bowl (e.g., Lathrap 1971:Figure 10), and the Cueva de las Lechuzas pottery includes a wide-mouthed jar with a long neck and sharp bottom. Phase IV pottery from the Jancao site features specific decoration motifs and techniques that might have been selectively introduced into the local assemblage, instead of incorporating complete sets of vessel types and decorations.
The bottle with bridged handle is another vessel type that is possibly related to the eastern lowlands. We did not find any specimen that contained both sides of the vessel top, so it is impossible to determine whether this type can be included in what DeBoer (2003) called "Asymmetric Spouts of the Upper Amazon." However, this vessel's spout shape, with its relatively short and thick features, is similar to examples uncovered in the Upper Amazonian region.

\section{Interpretation of the Emergence and Development of the Early Pottery Assemblage in the Huánuco Region}

The Wairajirca pottery changed stepwise for several hundred years after the first appearance of pottery in the region. The features of this change can be summarized in three points: (1) diversification of vessel forms, (2) coexistence and fusion of different stylistic traditions within an assemblage, and (3) various technological innovations. In the early stages of this development track, neckless jars and simple form bowls were a fundamental component of the Wairajirca assemblage, as was the case with many highland and coastal sites, although Wairajirca pottery also included bottles with bridged handles. However, after the early fifteenth century cal BC, the variety of vessel forms increased over time, and a unique assemblage composed of various vessels consequently formed around the early thirteenth century cal BC.

The diversification of forms in the later phases of Wairajirca pottery corresponds, at least to an extent, to a stylistic change. When the widemouthed jar was first introduced into the Wairajirca assemblage in Phase III, it originated a different style, unique to this type of jar, that appears to have been incorporated into Phase IV's local style. This phase's neckless jar inherited characteristics of the previous phase's arcshaped motif tradition, but it also presented some traits of Phase III's wide-mouthed jar, including small circle lines and dots under the ridged rim, the red slip technique, and so on. In contrast, the hatching style's geometric motifs that appeared in Phase IV did not mix with the local stylistic tradition. This style was limited to bowls, and the various types of decorated 
bowls that appeared in the last phase were all associated with this style. Consequently, such a step-by-step introduction of different stylistic traditions results in the unique features of Wairajirca pottery that contain two distinctive styles in one assemblage.

In addition, these developments were followed by technological advances. Some techniques, such as red slips, circle-and-dot stamps that require special instruments, and postfiring pigments with hatchings curved by sharp pointed tools, were adopted at the same time as new styles were introduced into the Wairajirca assemblage.

All these features of Wairajirca pottery development indicate that various sociopolitical, economic, and ideological factors were involved in the emergence and development of pottery in the Huánuco region. The increasing need over time for elaborated ceramic vessels for utilitarian/ non-utilitarian purposes and an intensifying social exchange during the frontier situation likely caused rapid stylistic changes in pottery; in addition, various forms of social interaction likely promoted the "dependent invention" (Clark and Gosser 1995) process of pottery technology.

The data for interpreting the first stage of this process - the first acceptance of pottery into previously preceramic lifestyles - are still limited, but it appears that pottery's use in the first phase was more restricted than in the later phases. This phase's ceramic assemblage only included the neckless jar, unlike in other phases, perhaps because serving various types of foods in ceramic vessels was not fully established at this time. In addition, this period's pottery did not appear to serve as a food-processing tool. Rather, people in this region possibly began to use pottery as a replacement for earlier perishable containers, such as gourds, in response to increasing needs for more durable vessels. In fact, some scholars claim that the neckless jar was originally created by mimicking precedent gourd containers; the Huaricoto site's researcher declared that pottery was experimentally invented in some Andean locations, including in this site (Burger 1988). Although it is unclear whether this experimental phase existed in the Huánuco region, interactions with neighboring highland regions likely play an important role in this first step of pottery technology introduction, especially considering the early pottery similarities in the broad highland areas described earlier. Phase II contained other vessel forms (bowls and bottles) that represented the local stylistic tradition of the Wairajirca assemblage. Perhaps human practices related to pottery had gradually developed in various social domains as features of ceramic vessels, which were sufficiently plastic to represent various things and became durable enough for multiple purposes after firing, were further understood.

Fluid interactions with neighboring lowlands that had their own ceramic traditions before pottery emerged would have facilitated the development of pottery use in the Huánuco region. Bottles with bridged handles that appeared from Phase II were likely directly imported to this region from the lowlands and became a new component of the highlands' neckless jar's dominant assemblage. As seen in wide-mouthed jars in Phase III, the new style's emergence, closely associated with the introduction of new technology, indicated a direct communication between local potters and foreign ones that resulted in a knowledge transfer-including that related to potters' motor habits and the making of special tools for pottery production. This interaction with the lowlands area seems to have increased beginning with this phase; perhaps a number of people immigrated from areas where this stylistic tradition originally existed to the Huánuco region's local communities. In addition, although there is still little evidence for the utilization of food resources at this time, certain changes in local dietary habits may have prompted increased needs for new jar forms (cf. Onuki 1982).

Such a fluid interaction among the highlands and the lowlands is closely associated with internal sociopolitical movements or social structural changes in the frontier region, and these would also play a crucial role in the process of pottery development. The set of bowls sharing an elaborated geometric style that emerged during Phases IV and V suggests a specific function, likely for non-utilitarian purposes. In two reports of the Shillacoto site excavation (Izumi et al. 1972; Kano 1979), the vast majority of pottery 
figures associated with an altar-like tomb belonged to this group of bowls; some had jaguar and other rain forest animal motifs incorporated in their geometric style. Such a special set of bowls might reflect certain sociopolitical needs, such as ritual ceremonies. In addition, new chronology revealed that the Kotosh and Shillacoto sites, both known for preceramic monumental architectures, were not occupied at the beginning of the Wairajirca phase but appear to have been reoccupied in Phase III. Another site was also occupied from Phase IV in the southern part of the region. Considering these cases, we can argue that some social changes, stemming from both internal and external factors during this period, led to the elaboration of ceramic vessels and their use.

As briefly illustrated earlier, the emergence and development of Wairajirca pottery can be traced as the practices related to the use of ceramic vessels developed, according to the social situation of the times in the second millennium BC. From daily life communications among individuals to single or periodic migration, various forms of human and object mobility must have existed in this frontier region, and the movement of pots, potters, and pottery knowledge directly triggered changes in ceramic form, style, and technology in various ways (Heitz and Stapfer 2017; Imamura 2011). This region's favored natural environment, containing various types of resources in high availability, also might have affected the course of pottery improvement. In sum, in the Huánuco region, pottery technology was developed through accepting and reinterpreting various elements from other regions in its own sociopolitical context and subsequently occurring unique features of Wairajirca pottery.

\section{Conclusion}

Our new approach to developing a chronology of the Early Formative period enabled us to trace the chronological development of Wairajirca pottery over centuries, detailing vessel form diversification, a stylistic dichotomy, and technological improvements. A brief comparative review with other regions based on this high-resolution ceramic chronology indicates that the dynamic interactions in this period across different ecological zones strongly influenced the unique features of this pottery's development track. In addition, certain attributes of the ceramic types and their chronological changes, such as specific decorative motifs and the applied techniques, suggest that varying types and levels of human mobility would have been necessary for such interactions to occur.

Acknowledgments. We thank Dr. Yoshio Onuki and Dr. Tatsuhiko Fujii for their generous support for all work conducted in Huánuco city. We are grateful to the members of the Jancao excavation team, especially Lissete Acuña, Cesar Sara Repetto, Hironori Otani, and Syunsuke Inoue. The assistance of Gustavo Zumarán and Danilo Depaz in analysis work was invaluable. Advice and comments given by Dr. Hiroyuki Sato and Dr. Jason Nesbitt have been a great help in developing our discussion. We thank Dr. Hitoshi Yonenobu for encouragement and advice. This work was supported by Grant-in-Aid for Scientific Research No. 17H05110, 17H05111, 20J14587 and the Takanashi Foundation for Historical Science.

Data Availability Statement. The materials showed in this article are curated in the facilities of the Ministerio de Cultura in Huánuco, Peru. All the data related to this study are available by request of the authors.

Supplemental Material. For supplemental material accompanying this article, visit https://doi.org/10.1017/laq.2020.89.

Supplemental Figure 1. Plan of the Jancao site.

Supplemental Figure 2. Photographs of the Jancao site.

Supplemental Figure 3. Photographs of carbon samples from the Jancao site.

Supplemental Figure 4. Drawings of rim sherds pertaining to Phase I-II, unearthed in E1S2.

Supplemental Figure 5. Drawings of rim sherds pertaining to Phase III-IV, unearthed in E1S2.

Supplemental Figure 6. Drawings of rim sherds pertaining to Phase V, unearthed in E1S2-3.

Supplemental Figure 7. Drawings of rim sherds pertaining to Phase II-V, unearthed in E1N4.

Supplemental Figure 8. Photographs of rim sherds pertaining to Phase I-III.

Supplemental Figure 9. Photographs of rim sherds pertaining to Phase IV-V

Supplemental Figure 10. Stratigraphic relations of radiocarbon samples from the Jancao site.

Supplemental Note 1. OxCal CQL2 codes.

Supplemental Table 1. Comparison of Modeled Dates Derived from the SHCal Model, Charcoal Model, and Mixing Curve Model.

\section{References Cited}

Bronk Ramsey, Christopher

1995 Radiocarbon Calibration and Analysis of Stratigraphy: The OxCal Program. Radiocarbon 37:425-430. 1998 Probability and Dating. Radiocarbon 40:461-474. 2009a Bayesian Analysis of Radiocarbon Dates. Radiocarbon 51:337-360. 
2009b Dealing with Outliers and Offsets in Radiocarbon Dating. Radiocarbon 51:1023-1045.

Burger, Richard L.

1985 Prehistoric Stylistic Change and Cultural Development at Huaricoto, Peru. National Geographic Research 1:505-534.

1988 The Beginning of Ceramic Use in Peru as Viewed from Huaricoto. Paleoetonológica 5:259-266.

1992 Chavin and the Origins of Andean Civilization. Thames and Hudson, London.

Chávez, Karen Lynne Mohr

1977 Marcavalle: The Ceramics from an Early Horizon Site in the Valley of Cusco, Peru, and Implications for South Highland Socioeconomic Interaction. PhD dissertation, Department of Anthropology, University of Pennsylvania, Philadelphia.

Christen, Andrés J.

1994 Summarizing a Set of Radiocarbon Determinations: A Robust Approach. Journal of the Royal Statistical Society: Series C (Applied Statistics) 43:489-503.

Clark, John E., and Dennis Gosser

1995 Reinventing Mesoamerica's First Pottery. In The Emergence of Pottery Technology and Innovation in Ancient Societies, edited by William K. Barnett and John W. Hoopes. Smithsonian Institution, Washington, DC.

DeBoer, Warren D.

2003 Ceramic Assemblage Variability in the Formative of Ecuador and Peru. In Archaeology of Formative Ecuador, edited by Scott J. Raymond and Richard L. Burger, pp. 289-336. Dumbarton Oaks, Washington, DC.

Ford, James A.

1969 A Comparison of Formative Cultures in the Americas: Diffusion or the Psychic Unity of Man? Smithsonian Contributions to Archaeology 11. Smithsonian Institution, Washington, DC.

Grieder, Terence E.

1988 Ceramics. In La Galgada, Peru: A Preceramic Culture in Transition, edited by Terence Grieder, Alberto Bueno Mendoza, C. Earle Smith Jr., and Robert M. Malina, pp. 185-191. University of Texas Press, Austin.

Grossman, Joel W.

1983 Demographic Change and Economic Transformation in the South-Central Highlands of Pre-Huari Peru. Nawpa Pacha 21:45-126.

Heitz, Caroline, and Regine Stapfer

2017 Mobility and Pottery Production, What for? Introductory Remarks. In Mobility and Pottery Production: Archaeological and Anthropological Perspectives, edited by Caroline Heitz and Regine Stapfer, pp. 11-38. Sidestone Press, Leiden.

Hogg, G. Alan, Quan Hua, Paul G. Blackwell, Mu Niu, Caitlin E. Buck, Thomas P. Guilderson, Timothy J. Heaton, Jonathan G. Palmer, Paula J. Reimer, Ron W. Reimer, Christian S. M. Turney, and Susan R. H. Zimmerman

2013 SHCal13 Southern Hemisphere Calibration, 050,000 Years cal BP. Radiocarbon 55:1889-1903.

Hoopes, John W.

1994 Ford Revisited: A Critical Review of the Chronology and Relationships of the Earliest Ceramic Complexes in the New World, 6000-1500 B.C. Journal of World Prehistory 8:1-49.

Imamura, Keiji

2011 Ikeitou Doki no Deai: Dokikenkyu no Kanousei wo Motomete. In Ikeitou Doki no Deai, edited by Keiji Imamura, pp. 1-26. Douseisya, Tokyo.
Inokuchi, Kinya, Yoshio Onuki, Eisei Tsurumi, Yuichi Matsumoto, and Alvaro Ruiz

2002 Preliminary Report of the General Survey in Huánuco, Peru. América Antigua 5:69-88.

Izumi, Seiichi, Pedro Cuculiza, and Chiaki Kanō

1972 Excavations at Shillacoto, Huánuco, Peru. University Museum Bulletin No. 3. Tokyo University, Tokyo.

Izumi, Seiichi, and Tosihiko Sono

1963 Andes 2: Excavations at Kotosh, Peru, 1960. Kadokawa, Tokyo.

Izumi, Seiichi, and Kazuo Terada

1972 Andes 4: Excavations at Kotosh, Peru, 1963 and 1966. University of Tokyo Press, Tokyo.

Kano, Chiaki

1979 The Origins of the Chavin Culture. Dumbarton Oaks, Washington, DC.

Kaulicke, Peter

1981 Keramik der fruhen Intialperiode aus Pandanche, Dpto. Cajamarca, Peru. BAVA 3:363-389.

Lathrap, Donald W.

1962 Yarinacocha: Stratigraphic Excavations in the Peruvian Montaña. PhD dissertation, Department of Anthropology, Harvard University, Cambridge, Massachusetts.

1970 The Upper Amazon. Thames and Hudson, London. 1971 The Tropical Forest and the Cultural Context of Chavín. In Dumbarton Oaks Conference on Chavín, October 26th and 27th, 1968, edited by Elizabeth P. Benson, pp. 73-100. Dumbarton Oaks, Washington, DC.

Lathrap, Donald W., and Lawrence Roys

1963 The Archaeology of the Cave of the Owls in the Upper Montana of Peru. American Antiquity 29:27-38.

Marsh, Erik J., Maria C. Bruno, Sherilyn C. Fritz, Paul Baker, José M. Capriles, and Christine A. Hastorf

2018 IntCal, SHCal, or a Mixed Curve? Choosing a ${ }^{14} \mathrm{C}$ Calibration Curve for Archaeological and Paleoenvironmental Records from Tropical South America. Radiocarbon 60:925-940.

Matsumoto, Go

2014 Ancestor Worship in the Middle Sicán Theocratic State. PhD dissertation, Department of Anthropology, Southern Illinois University, Carbondale.

Matsumoto, Yuichi

2020 Prehistoric Settlement Patterns in the Upper Huallaga Basin, Peru. Yale University Press, New Haven, Connecticut.

Meggers, Betty J., Clifford Evans, and Emilio Estrada

1965 Early Formative Period of Coastal Ecuador. Smithsonian Institution, Washington, DC.

Morales, Daniel

1977 Investigaciones arqueológicas en Las Salinas de San Blas (Junín) y sus implicancias en el periodo Formativo en la Sierra Central del Peru. Bachelor's thesis, Departmento de Arqueología, Universidad Nacional de San Marcos, Lima.

1998 Importancia de Las Salinas de San Blas durante el periodo Formativo en La Sierra Central del Perú. Boletín de Arqueología PUCP 2:273-288.

Nesbitt, Jason, Belkys Gutiérrez, and Segundo Vásquez

2010 Excavaciones en Huaca Cortada, complejo Caballo Muerto: Un informe preliminar. Boletín de Arqueología PUCP 12:261-286.

Onuki, Yoshio

1972 Pottery and Clay Artifacts. In Andes 4: Excavations 
at Kotosh, Peru, 1963 and 1966, edited by Seiichi Izumi and Kazuo Terada, pp. 177-248. University of Tokyo Press, Tokyo.

1982 Una perspectiva prehistórica de la utilización ambiental en la sierra nor-central de los Andes Centrales. In El hombre y su ambiente en los Andes Centrales, edited by Luis Millones and Hiroyasu Tomoeda, pp. 211-228. National Museum of Ethnology, Osaka, Japan.

1993 Las actividades ceremoniales tempranas en la cuenca del alto Huallaga y algunos problemas generales. In El mundo ceremonial andino, edited by Luis Millones and Yoshio Onuki, pp. 69-96. National Museum of Ethnology, Osaka, Japan.

Parker, Bradley J.

2006 Toward an Understanding of Borderland Processes. American Antiquity 71:77-100.

Pulgar Vidal, Javier

1987 Geografía del Perú: Las ocho regiones naturales (nueva edición). PEISA, Lima.

Shady, Ruth

1987 Tradición y cambio en las sociedades formativas de Bagua, Amazonas, Perú. Revista Andina 2:457-487.
Terada, Kazuo

1979 Excavations at La Pampa in the North Highland of Peru, 1975. University of Tokyo Press, Tokyo.

Terada, Kazuo, and Yoshio Onuki

1985 The Formative Period in the Cajamarca Basin: Excavations at Huacaloma and Layzón, 1982. University of Tokyo Press, Tokyo.

Toshihara, Kayoko

2002 The Cupisnique Culture in the Formative Period World of the Central Andes, Peru. PhD dissertation, Department of Anthropology, University of Illinois, Urbana-Champaign.

Tsurumi, Eisei

2010 La secuencia cronológica de los centros ceremoniales de la Pampa de Las Hamacas y Tembladera, valle medio de Jequetepeque. Boletín de Arqueología PUCP 12:141-169.

Submitted August 14, 2019; Revised February 20, 2020; Accepted October 30, 2020 